University of Nebraska - Lincoln

DigitalCommons@University of Nebraska - Lincoln

USDA National Wildlife Research Center - Staff Publications
U.S. Department of Agriculture: Animal and Plant Health Inspection Service

2013

\title{
Wildlife Contact Rates at Artificial Feeding Sites in Texas
}

Tyler A. Campbell

United States Department of Agriculture, Animal and Plant Health Inspection Service, Wildlife Services, National Wildlife Research Center, Florida Field Station, tcampbell@eastfoundation.net

David Long

United States Department of Agriculture, Animal and Plant Health Inspection Service, Wildlife Services, National Wildlife Research Center, Florida Field Station

Susan A. Shriner

USDA/APHIS/WS National Wildlife Research Center, susan.a.shriner@aphis.usda.gov

Follow this and additional works at: https://digitalcommons.unl.edu/icwdm_usdanwrc

Campbell, Tyler A.; Long, David; and Shriner, Susan A., "Wildlife Contact Rates at Artificial Feeding Sites in Texas" (2013). USDA National Wildlife Research Center - Staff Publications. 1392.

https://digitalcommons.unl.edu/icwdm_usdanwrc/1392

This Article is brought to you for free and open access by the U.S. Department of Agriculture: Animal and Plant Health Inspection Service at DigitalCommons@University of Nebraska - Lincoln. It has been accepted for inclusion in USDA National Wildlife Research Center - Staff Publications by an authorized administrator of DigitalCommons@University of Nebraska - Lincoln. 


\title{
Wildlife Contact Rates at Artificial Feeding Sites in Texas
}

\author{
Tyler A. Campbell • David B. Long • \\ Susan A. Shriner
}

Received: 29 June 2012/ Accepted: 4 March 2013 / Published online: 23 April 2013

(C) Springer Science+Business Media New York (outside the USA) 2013

\begin{abstract}
Given the popularity of feeding white-tailed deer (Odocoileus virginianus) in Texas and the increasing amount of corn that is distributed, more information is needed on the impacts of this activity on non-target wildlife. Our objectives were to report visitation, intra- and interspecific contact, and contact rates of wildlife at artificial feeding sites in Texas. Our study was conducted at three sites in Kleberg and Nueces counties, Texas. We trapped animals from February to April and August to September, 2009 and marked animals with passive integrated transponder (PIT) tags. At each site and season, we placed one feeder system containing a PIT tag reader within $600 \mathrm{~m}$ of trap locations. Readers detected PIT tags from a distance of $25 \mathrm{~cm}$. We determined a contact event to occur when two different PIT tags were detected by feeder systems within $5 \mathrm{~s}$. We recorded 62,719 passes by raccoons (Procyon lotor), 103,512 passes by collared peccaries (Pecari tajacu), 2,923 passes by feral swine (Sus scrofa), 1,336 passes by fox squirrels (Sciurus niger), and no passes by opossums (Didelphis virginiana) at feeder
\end{abstract}

T. A. Campbell · D. B. Long

United States Department of Agriculture, Animal and Plant Health Inspection Service, Wildlife Services, National Wildlife Research Center, Florida Field Station, 2820 East University Avenue, Gainesville, FL 32641, USA

Present Address:

T. A. Campbell $(\square)$

East Wildlife Foundation, 200 Concord Plaza, Suite 410,

San Antonio, TX 78216, USA

e-mail: tcampbell@eastfoundation.net

\section{S. A. Shriner}

United States Department of Agriculture, Animal and Plant Health Inspection Service, Wildlife Services, National Wildlife Research Center, 4101 LaPorte Avenue, Fort Collins, CO 80521, USA systems. For site-season combinations in which contact events occurred, we found intraspecific contact rates (contacts per day) for raccoons, collared peccaries, and feral swine to

be $0.81-124.77,0.69-38.08$, and $0.0-0.66$, respectively. Throughout our study we distributed $\sim 2,625 \mathrm{~kg}$ of whole kernel corn, which resulted in 6,351 contact events between marked wildlife ( 2.4 contacts per $\mathrm{kg}$ of corn). If 136 million $\mathrm{kg}$ of corn is distributed in Texas annually, we would expect $>5.2$ billion unnatural contact events between wildlife would result from this activity each year in Texas. Consequently, we do not believe that it is wise for natural resource managers to maintain artificial feeding sites for white-tailed deer or other wildlife due to pathogen transmission risks.

Keywords Bait - Collared peccary $\cdot$ Contact rate $\cdot$ Feral swine $\cdot$ Passive integrated transponder tag $\cdot$ Raccoon

\section{Introduction}

It has been estimated that 136 million $\mathrm{kg}$ of whole kernel corn is distributed by hunters and wildlife enthusiasts annually in Texas (Wilkins and others 1999). The intended purposes of this activity are to supplement natural food that may be limited, enhance productive processes, increase survival, facilitate observation, and successfully harvest white-tailed deer (Odocoileus virginianus; Hansen 2011). There is growing trepidation about the impact of feeding deer on population health (Brown and Cooper 2006) and ecological processes (Cooper and others 2006). A major concern of wildlife health professionals is that feeding deer increases their concentration at feeding sites, where direct or indirect pathogen transmission may occur (Thompson and others 2008). 
Feeding deer may have consequences within other wildlife populations (Moseley and others 2011). Specifically, wildlife populations with access to artificial feed may display greater fecundity, recruitment, and survival (Boutin 1990; O’Donoghue and Krebs 1992), resulting in increased abundance and density (Brown and Cooper 2006), and nest predation (Cooper and Ginnett 2000). Feeding sites may also function to concentrate wildlife, leading to increased intra- and interspecific interaction, and contact (Williamson 2000). For example, common feeding sites in rural eastern Ontario were identified as foci for the spread of rabies virus in raccoons (Procyon lotor) due to the high number of intraspecific contacts that occurred there (Totton and others 2002). Given the popularity of feeding deer in Texas and the increasing amount of corn and other rations that are distributed, more information is needed on the impacts of this activity on non-target wildlife.

Our objectives with this descriptive study were to report visitation, intra- and interspecific contact, and contact rates of wildlife at artificial feeding sites in Texas using passive integrated transponder (PIT) tag technology. We expected contact rates of wildlife to be equal to or exceed $0.99-1.28$ contacts per hour observed within raccoons at a common feeding site in rural eastern Ontario (Totton and others 2002) because of the diverse assemblage and abundance of wildlife in Texas and their affinity for artificial feed (Lambert and Demarais 2001).

\section{Methods}

Our study was conducted at three sites in Kleberg and Nueces counties, Texas from February to November 2009. Two sites were owned by Texas A\&M University-Kingsville $\left(27^{\circ} 28^{\prime} \mathrm{N}, 97^{\circ} 53^{\prime} \mathrm{W} ; 27^{\circ} 32^{\prime} \mathrm{N}, 97^{\circ} 52^{\prime} \mathrm{W}\right)$ and one site was owned by a private landowner $\left(27^{\circ} 34^{\prime} \mathrm{N}, 97^{\circ} 51^{\prime} \mathrm{W}\right)$. All three sites occurred in the eastern Rio Grande Plains ecoregion (Gould 1975). Overstory vegetation was predominated by honey mesquite (Prosopis glandulosa), huisache (Acacia smallii), and granjeno (Acacia berlandieri). Understory vegetation was predominated by pricklypear cactus (Opuntia lindheimeri) and bufflegrass (Cenchrus ciliaris). The sites received an average of $74.7 \mathrm{~cm}$ of precipitation per year (National Climatic Data Center, http://hurricane.ncdc.noaa.gov/ancsum/ACS).

At each site, we trapped animals from February to April and August to September using four rooter-door box traps $(2.5 \mathrm{~m} \times 1 \mathrm{~m} \times 1 \mathrm{~m})$ and four mesomammal live traps (Model 108, Tomahawk Live Trap, Tomahawk, WI, USA) placed near box traps. We baited both types of traps with whole kernel corn. Traps were checked daily just after sunrise. Upon capture, we estimated weight and chemically immobilized animals, following established dosages
(Kreeger and others 2002), with a syringe or pole syringe (Dan-Inject Dart Guns, Austin, TX, USA) equipped with a ketamine, Telazol ${ }^{\circledR}$, and/or xylazine combination syringe. We determined sex and externally marked animals with ear tags (National Band and Tag Company, Newport, KY, USA). Additionally, we internally marked animals with PIT tags (Biomark, Inc., Boise, ID, USA). We injected PIT tags subcutaneously between the scapulae and base of the cranium in raccoons, opossums (Didelphis virginiana), and fox squirrels (Sciurus niger), and behind the right mandible in feral swine (Sus scrofa) and collared peccaries (Pecari tajacu). After handling, we used an intramuscular injection of yohimbine hydrochloride, following established dosages (Kreeger and others 2002), as a reversal agent, and allowed animals to recover at their site of capture.

At each site, we placed one feeder system $<600 \mathrm{~m}$ from trap locations from April to May (spring) and October to November (autumn). We constructed feeders using $15.24 \mathrm{~cm}$ schedule 40 poly-vinyl-chloride (PVC) pipe and fittings (Charlotte Pipe and Foundry Company, Charlotte, NC, USA). Feeders consisted of two $15.24 \mathrm{~cm}$ caps (top and bottom), one $15.24 \mathrm{~cm}$ wye, and $2.0 \mathrm{~m}$ of $15.24 \mathrm{~cm}$ PVC pipe (Fig. 1). We secured feeders to native vegetation with nylon rope. We recorded use at each feeder using a FS2001F-ISO PIT tag reader (Biomark, Inc., Boise, ID, USA) with a "racket" style antenna mounted to the feeder (Fig. 1). We fastened the racket antenna to the feeder opening ( $45 \mathrm{~cm}$ from the ground) by inserting it between two custom fitted $1.9 \mathrm{~cm}$ treated plywood pieces on the PVC wye. We elevated the reader above the feeder in a ventilated case (Pelican Products, Inc., Torrance, CA, USA). For temperature regulation inside cases, we mounted a $12 \mathrm{v}$ fan (Startech.com, Lockbourne, OH, USA). We powered each reader and fan with an external $12 \mathrm{v}$ deep cycle battery and fastened the external battery and reader to a $1.9 \mathrm{~cm}$ treated plywood platform to ensure equipment stability. All wires connecting the antenna and the power source to the reader were sealed inside $1.9 \mathrm{~cm}$ Ultralite flex conduit (Southwire Company, Carrolton, GA, USA). We programmed each reader to delay $7 \mathrm{~s}$ between detections of the same animal; detections of different animals had no programmed delay. Readers detected PIT tags at a distance of $25 \mathrm{~cm}$. We visited each feeder system daily between 11:00 and 12:00 $\mathrm{h}$ to download data, replace batteries, and fill feeders with $\leq 15 \mathrm{~kg}$ of whole kernel corn, as needed. We monitored feeder systems with motion-sensing digital photography (RapidFire, Professional Edition, Reconyx, LaCrosse, WI). We placed cameras $10 \mathrm{~m}$ from feeder systems and programmed cameras to high sensitivity to capture digital images every $2 \mathrm{~s}$, for $10 \mathrm{~s}$ each time the camera system detected animal presence.

We assumed a contact event to occur when two different PIT tags were detected by feeder systems within $5 \mathrm{~s}$. We 
Fig. 1 Diagram of feeder system with passive integrated transponder tag reader, antenna, and power source at three sites in Kleberg and Nueces counties, Texas during spring (AprilMay) and autumn (OctoberNovember) 2009

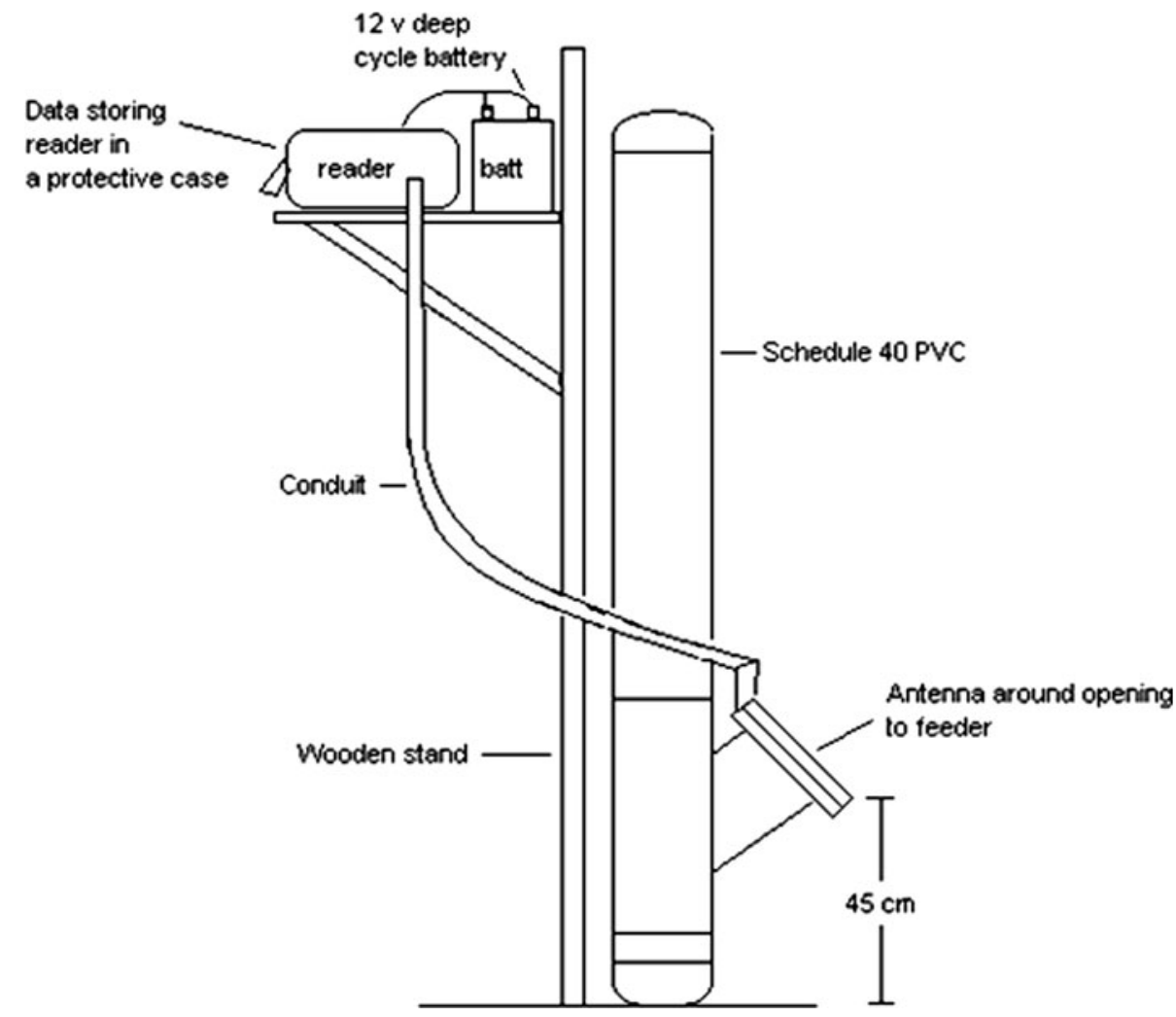

reported passage (detection of a PIT tag by the reader), intra- and interspecific contact, and contact rates (contacts per day or $24 \mathrm{~h}$ ) by site and season. Also, we compared the proportion of individuals visiting feeder systems that made contact with other individuals between males and females by species using the Chi square statistic with Yates correction (Alder and Roessler 1977). Furthermore, we reported mean $( \pm \mathrm{SE})$ percent of contact events for each species by hour. Lastly, from motion-sensing digital photography, we recorded the number of animals detected by hour with and without ear tags to determine the percent of visits by marked animals.

\section{Results}

At the Kleberg 1 site during spring, we trapped and marked 2 raccoons, 23 collared peccaries, 14 feral swine, and 1 opossum; we trapped and marked an additional raccoon, 7 collared peccaries, and 3 feral swine during autumn. At the Kleberg 2 site during spring, we trapped and marked 15 raccoons, 4 collared peccaries, 1 feral swine, and 1 opossum; during autumn we trapped and marked an additional 4 raccoons, 4 collared peccaries, and 8 feral swine. At the Nueces site during spring, we trapped and marked 13 raccoons, 29 feral swine, and 1 fox squirrel; we trapped and

Table 1 Number of passes by individuals (number of individuals passing/number of individuals tagged) with passive integrated transponder (PIT) tags at feeder systems containing PIT tag readers at three sites in Kleberg and Nueces counties, Texas during spring (April-May) and autumn (October-November) 2009

\begin{tabular}{|c|c|c|c|c|c|c|c|c|c|c|c|}
\hline \multirow[t]{3}{*}{ Site } & \multirow[t]{3}{*}{ Season } & \multicolumn{10}{|c|}{ Species } \\
\hline & & \multicolumn{2}{|c|}{ Raccoon } & \multicolumn{2}{|c|}{ Collared peccary } & \multicolumn{2}{|c|}{ Feral swine } & \multicolumn{2}{|c|}{ Squirrel } & \multicolumn{2}{|c|}{ Opossum } \\
\hline & & Passes & Individuals & Passes & Individuals & Passes & Individuals & Passes & Individuals & Passes & Individuals \\
\hline Kleberg 1 & Spring & 0 & $0 / 2$ & 40,242 & $17 / 23$ & 0 & $0 / 14$ & & & 0 & $0 / 1$ \\
\hline Kleberg 1 & Autumn & 208 & $1 / 3$ & 40,866 & $19 / 30$ & 0 & $0 / 17$ & & & 0 & $0 / 1$ \\
\hline Kleberg 2 & Spring & 27,973 & $12 / 15$ & 11,454 & $3 / 4$ & 0 & $0 / 1$ & & & 0 & $0 / 1$ \\
\hline Kleberg 2 & Autumn & 4,682 & $11 / 19$ & 10,948 & $3 / 8$ & 0 & $0 / 9$ & & & 0 & $0 / 1$ \\
\hline Nueces & Spring & 27,700 & $9 / 13$ & & & 2,923 & $13 / 29$ & 1,336 & $1 / 1$ & & \\
\hline Nueces & Autumn & 2,156 & $8 / 16$ & 2 & $1 / 1$ & 0 & $0 / 37$ & 0 & $0 / 1$ & & \\
\hline
\end{tabular}


Table 2 Number of individuals with PIT tags that visited feeder systems containing PIT tag readers and that made contact with other individuals with PIT tags (detections within $5 \mathrm{~s}$ of one another) by sex at three sites in Kleberg and Nueces counties, Texas during spring (April-May) and autumn (October-November) 2009

\begin{tabular}{|c|c|c|c|c|c|c|c|c|c|c|c|c|c|}
\hline \multirow[t]{4}{*}{ Site } & \multirow[t]{4}{*}{ Season } & \multicolumn{12}{|c|}{ Species } \\
\hline & & \multicolumn{4}{|c|}{ Raccoon } & \multicolumn{4}{|c|}{ Collared peccary } & \multicolumn{4}{|c|}{ Feral swine } \\
\hline & & \multicolumn{2}{|c|}{ Contact } & \multicolumn{2}{|c|}{ Visited } & \multicolumn{2}{|c|}{ Contact } & \multicolumn{2}{|c|}{ Visited } & \multicolumn{2}{|c|}{ Contact } & \multicolumn{2}{|c|}{ Visited } \\
\hline & & Male & Female & Male & Female & Male & Female & Male & Female & Male & Female & Male & Female \\
\hline Kleberg 1 & Spring & & & & & 7 & 7 & 9 & 8 & & & & \\
\hline Kleberg 1 & Autumn & 0 & 0 & 1 & 0 & 6 & 8 & 8 & 11 & & & & \\
\hline Kleberg 2 & Spring & 6 & 4 & 6 & 6 & 1 & 2 & 1 & 2 & & & & \\
\hline Kleberg 2 & Autumn & 5 & 5 & 5 & 6 & 1 & 2 & 1 & 2 & & & & \\
\hline Nueces & Spring & 2 & 7 & 2 & 7 & & & & & 2 & 6 & 3 & 10 \\
\hline Nueces & Autumn & 2 & 3 & 4 & 4 & 0 & 0 & 0 & 1 & & & & \\
\hline
\end{tabular}

Table 3 Days feeders systems were deployed, number of contacts, and contact rates (per day) by species or species combination at three sites in Kleberg and Nueces counties, Texas during spring (April-May) and autumn (October-November) 2009

\begin{tabular}{|c|c|c|c|c|c|c|c|c|c|c|}
\hline \multirow[t]{3}{*}{ Site } & \multirow[t]{3}{*}{ Season } & \multirow[t]{3}{*}{ Days } & \multicolumn{8}{|l|}{ Species } \\
\hline & & & \multicolumn{2}{|l|}{ Raccoon } & \multicolumn{2}{|c|}{ Collared peccary } & \multicolumn{2}{|c|}{ Feral swine } & \multicolumn{2}{|c|}{ Raccoon-collared peccary } \\
\hline & & & Contacts & $\begin{array}{l}\text { Contact rate } \\
\text { (per day) }\end{array}$ & Contacts & $\begin{array}{l}\text { Contact rate } \\
\text { (per day) }\end{array}$ & Contacts & $\begin{array}{l}\text { Contact rate } \\
\text { (per day) }\end{array}$ & Contacts & $\begin{array}{l}\text { Contact rate } \\
\text { (per day) }\end{array}$ \\
\hline Kleberg 1 & Spring & 32.55 & 0 & 0 & 843 & 25.9 & 0 & 0 & 0 & 0 \\
\hline Kleberg 1 & Autumn & 25.89 & 0 & 0 & 986 & 38.08 & 0 & 0 & 0 & 0 \\
\hline Kleberg 2 & Spring & 32.24 & 886 & 27.48 & 25 & 0.78 & 0 & 0 & 7 & 0.22 \\
\hline Kleberg 2 & Autumn & 31.77 & 510 & 16.05 & 22 & 0.69 & 0 & 0 & 1 & 0.03 \\
\hline Nueces & Spring & 24.3 & 3,032 & 124.77 & & & 16 & 0.66 & & \\
\hline Nueces & Autumn & 28.43 & 23 & 0.81 & 0 & 0 & 0 & 0 & & \\
\hline
\end{tabular}

marked an additional 3 raccoons, 1 collared peccary, and 8 feral swine during autumn.

We recorded 62,719 passes by raccoons, 103,512 passes by collared peccaries, 2,923 passes by feral swine, 1,336 passes by squirrels, and no passes by opossums at feeder systems (Table 1). During these passes, we observed 6,351 total contact events between marked wildlife, with a vast majority being intraspecific. For both raccoons and collared peccaries, we found 15 males and 19 females to contact other individuals (Table 2). For feral swine, we found two males and six females to contact other individuals. We did not find differences between sexes in the proportion of visiting raccoons $\left(\chi_{1}^{2}=0.60, P>0.10\right)$, collared peccaries $\left(\chi_{1}^{2}=0.64\right.$, $P>0.10)$, or feral swine $\left(\chi_{1}^{2}=0.76, P>0.10\right)$ that contacted other individuals (Table 2). For site-season combinations in which contact events occurred, we found intraspecific contact rates (contacts per day) for raccoons, collared peccaries, and feral swine to be 0.81-124.77, $0.69-38.08$, and $0.0-0.66$, respectively (Table 3 ). We found interspecific contact occurred between raccoons and collared peccaries only at the Kleberg 2 site at a rate (contacts per day) in spring and autumn of 0.22 and 0.03 , respectively. As expected, contact events for raccoons, collared peccaries, and feral swine primarily occurred during nocturnal hours; however, during spring, contact events for collared peccaries occurred in every hour, except 16:00 and 18:00 h (Fig. 2). From digital photography, we found $23 \%$ of visiting animals to be marked with ear tags.

\section{Discussion}

Our definition of contact incorporated spatial components (foraging at the same location) and temporal components (within $5 \mathrm{~s}$ of one another). We considered $5 \mathrm{~s}$ a conservative definition, as transmission that occurred via feed contamination could occur at intervals in excess of $5 \mathrm{~s}$. Salivary, eye, or nasal excretions could contaminate feed, and for many agents, live pathogens would be available for more than $5 \mathrm{~s}$ (e.g., influenza or rabies viruses) (Wobeser 

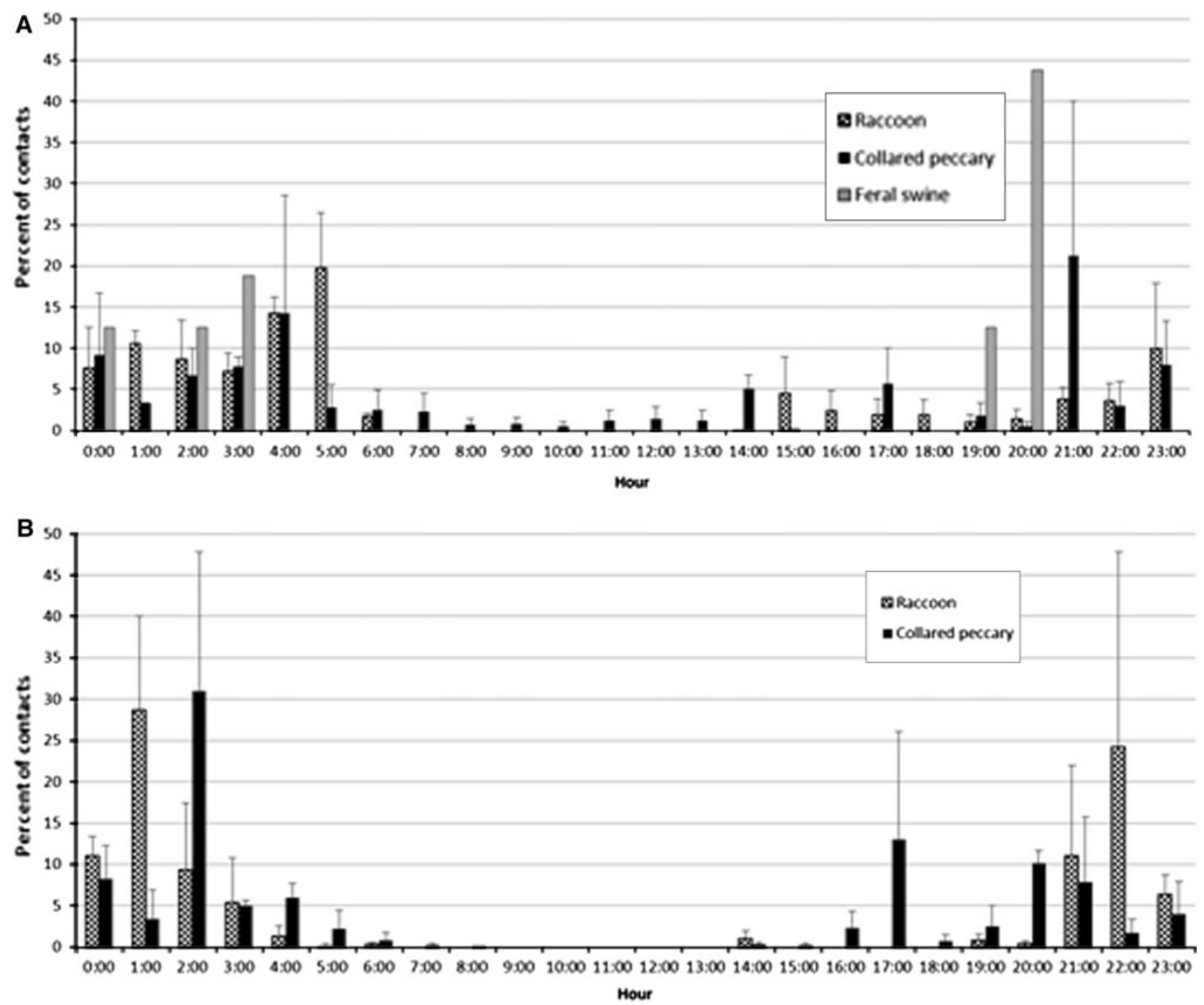

Fig. 2 Mean $( \pm \mathrm{SE})$ percent of contact events for each species by hour at three sites in Kleberg and Nueces counties, Texas during a spring (April-May) and b autumn (October-November) 2009

2006). Due to high visitation by wildlife at feeder stations and mixed-sex composition within species, other transmission routes (e.g., fecal or sexual contact) were also likely present.

Overall, a high proportion of available raccoons $(60 \%)$ and collared peccaries $(65 \%)$ visited feeder stations; however, only $12 \%$ of available feral swine visited feeder stations and this occurred at only one site-season combination. This result was surprising given the affinity that feral swine have for whole kernel corn (Williams and others 2011) and suggests that feral swine may have avoided our feeder systems due to neophobia or other factors. Given that feral swine were hunted and trapped in or around our sites, an alternative explanation for their low visitation was that they were removed by recreationalists and not available during periods of study or that they were more wary than species that were not hunted.

We did not observe patterns in contact among seasons, sites, or sexes. For example, the proportion of visiting wildlife that contacted other individuals did not vary between sexes. Interestingly, the Nueces County site during autumn had a notably low number of contact events. In fact, contact rates for raccoons in Nueces County were 154 times less during autumn ( 8 raccoons visiting) than spring (9 raccoons visiting). Our autumn study period coincided with the deer hunting season and the landowner maintained 5 deer feeders $<500 \mathrm{~m}$ from our feeder system. Consequently, it is likely that these other feeders dispersed animals throughout the property resulting in lower visitation and contacts at our feeder system. 
As expected, our wildlife contact rates compared favorably to the $0.99-1.28$ contacts per hour observed within raccoons at a common feeding site raccoons in rural eastern Ontario (Totton and others 2002). An exception to this was the extraordinary contact rate we observed in Nueces County during the spring. In this site-season combination, 3,032 contacts occurred among 9 raccoons in $583.2 \mathrm{~h}$ of observation (5.20 contacts per hour), including diurnal hours when very few contacts occurred. A possible explanation for this high rate of contact relates to the fact that this population was fed during other times of the year. In turn, raccoon population densities may have been artificially high, resulting in food shortages and their gregarious behavior at our feeder system.

Our interspecific contact rates were relatively low. However, during both seasons at the Kleberg 2 site we observed contacts between raccoons and collared peccaries. Overall, this site had a high number of raccoon visits and a moderate number of collared peccary visits. This suggests that in situations where both species readily visit feeders, they will contact one another; we observed this occurring at a maximum rate of once every 4.5 days. Additionally, during spring at the Nueces site where feral swine visited, we observed little commingling of different wildlife species. The squirrel visited the feeder system during diurnal hours and in the event that feral swine visited, raccoons typically did not visit until several hours later.

Throughout our study we distributed $\sim 2,625 \mathrm{~kg}$ of whole kernel corn, which resulted in 6,351 contact events between marked wildlife (2.4 contacts per $\mathrm{kg}$ of corn). Also, only 1 in 4 animals visiting feeder systems were marked and a contact event required 2 marked individuals $(1 / 4 \times 1 / 4=1 / 16)$. Consequently, we estimate that 38.4 contacts $(2.4 \times 16)$ occurred per $\mathrm{kg}$ of corn distributed. This figure does not include contact events that occurred with species of wildlife that were unmarked or those that occurred outside the detection distance of PIT tag readers $(25 \mathrm{~cm})$, and is conservative. For example, we did not attempt to quantify visitation by white-tailed deer or avian species to the feeder systems. Given that 136 million $\mathrm{kg}$ of corn is distributed in Texas annually (Wilkins and others 1999), it is reasonable to expect that $>5.2$ billion unnatural contact events $(136$ million $\mathrm{kg}$ of corn $\times 38.4$ contacts per $\mathrm{kg}$ of corn) between wildlife would result from this activity each year in Texas. Additionally, many property owners artificially feed rations other than corn, such as protein pellets (Lambert and Demarais 2001), which are not considered here. In this age of heightened awareness of human-wildlife-livestock disease systems and threats, we do not believe that it is wise for natural resource managers to maintain artificial feeding sites for white-tailed deer or other wildlife. These recommendations are consistent with those made by other researcher using different methods
(Thompson and others 2008). In the event that feeding deer is unavoidable, due to social or other pressures, we recommend managers use exclusion devices for non-target wildlife to reduce contact and threats of pathogen transmission (Rattan and others 2010).

Acknowledgments We thank Michael Benton and Texas A\&M University-Kingsville for providing access to conduct research. We are grateful to Crysta Brock, Shyla Rabe, Justin Rattan, and Richie Sinclair for assistance in data collection. Financial support was provided by USDA APHIS Wildlife Services National Wildlife Research Center. Our mention of commercial products herein is for identification purposes and does not constitute endorsement or censure by the United States Department of Agriculture. All experimental procedures were approved by the Institutional Animal Care and Use Committee at the National Wildlife Research Center (Permit No. QA1593).

Ethical Standards Experiments contained within this manuscript comply with current laws of the United States of America.

Conflict of interest The authors declare that they have no conflict of interest.

\section{References}

Alder HL, Roessler EB (1977) Introduction to probability and statistics, 6th edn. Freeman, San Francisco

Boutin S (1990) Food supplementation experiments with terrestrial vertebrates: patterns, problems, and the future. Can J Zool 68:203-220

Brown RD, Cooper SM (2006) The nutritional, ecological, and ethical arguments against baiting and feeding white-tailed deer. Wildl Soc Bull 34:519-524

Cooper SM, Ginnett TF (2000) Potential effects of supplemental feeding of deer on nest predation. Wildl Soc Bull 28:660-666

Cooper SM, Owens MK, Cooper RM, Ginnett TF (2006) Effect of supplemental feeding on spatial distribution and browse utilization by white-tailed deer in semi-arid rangeland. J Arid Environ 66:716-726

Gould FW (1975) Texas plants—a checklist and ecological summary. Texas Agricultural Experiment Station, Texas A\&M University, College Station

Hansen L (2011) Extensive management. In: Hewitt DG (ed) Biology and management of white-tailed deer. CRC Press, Boca Raton

Kreeger TJ, Arnemo JM, Raath JP (2002) Handbook of wildlife chemical immobilization, international edition. Wildlife Pharmaceuticals, Fort Collins

Lambert BC, Demarais S (2001) Use of supplemental feed for ungulates by non-target species. Southwest Nat 46:118-121

Moseley WA, Cooper SM, Hewitt DG, Fulbright TE, DeYoung CA (2011) Effects of supplemental feeding and density of whitetailed deer on rodents. J Wildl Manag 75:675-681

O'Donoghue M, Krebs CJ (1992) Effects of supplemental food on snowshoe hare reproduction and juvenile growth at a cyclic population peak. J Anim Ecol 61:631-641

Rattan JM, Higginbotham BJ, Long DB, Campbell TA (2010) Exclusion fencing for feral hogs at white-tailed deer feeders. Tex J Agric Nat Resour 23:83-89

Thompson AK, Samuel MD, Van Deelen TR (2008) Alternative feeding strategies and potential disease transmission in Wisconsin white-tailed deer. J Wildl Manag 72:416-421 
Totton SC, Tinline RR, Rosatte RC, Bigler LL (2002) Contact rates of raccoons (Procyon lotor) at a communal feeding site in rural eastern Ontario. J Wildl Dis 38:313-319

Wilkins N, Brown RD, Steinbach DW (1999) Reducing risks to wildlife from corn contaminated with aflatoxins. Department of Wildlife and Fisheries, Texas A\&M University, Annual Report (1997-1998), College Station
Williams BL, Holtfreter RW, Ditchkoff SS, Grand JB (2011) Efficiency of time-lapse intervals and simple baits for camera surveys of wild pigs. J Wildl Manag 75:655-659

Williamson SJ (2000) Feeding wildlife-just say no!. Wildlife Management Institute, Washington, DC

Wobeser GA (2006) Essentials of disease in wild animals. Blackwell, Ames 